\title{
TEACHING SEMANTIC THROUGH JIGSAW MODEL: AN OVERVIEW OF LESSON STUDY FOR LEARNING COMMUNITY (LSLC) IMPLEMENTATION
}

\author{
Bobi Arisandi
}

\begin{abstract}
Lesson Study for Learning Community (LSLC) adalah program yang dilaksanakan untuk memecahkan masalah belajar mengajar di kalangan dosen di ruang kelas di STKIP Muhammadiyah-Kotabumi, Lampung. Proses ini dibagi menjadi 3 langkah yaitu , $P L A N "$ "DO”, dan" SEE”. Dalam penelitian ini, LSLC diimplementasikan dalam mata kuliah "Semantik". Semantik adalah salah satu cabang dalam ilmu linguistik yang dipelajari Jurusan Bahasa Inggris STKIP Muhammadiyah-Kotabumi, Lampung. Selama kegiatan belajar mengajar, dosen menggunakan model pembelajaran jigsaw untuk mempermudah materi yang luas yang perlu dipelajari oleh siswa. Dalam program LSLC, dosen diawasi oleh pengamat dalam tiga langkah kegiatan LSLC (Plan, Do, See). Tujuan dari penelitian ini adalah untuk menganalisis pengajaran "Semantik" dengan menggunakan model jigsaw ketika LSLC dilaksanakan. Qualitative narrative digunakan sebagai desain penelitian sementara data dikumpulkan dengan menggunakan observasi kelas. Di atas semua, hasil penelitian ini mempromosikan pemahaman yang mendalam tentang bagaimana pengajaran "Semantik" dengan menggunakan model jigsaw ketika LSLC dilaksanakan.
\end{abstract}

Keywords: semantic, LSLC, jigsaw

\section{INTRODUCTION}

Semantic is one of the courses that is taught in Sekolah Tinggi Keguruan dan Ilmu Pendidikan (STKIP) Muhammadiyah Kotabumi, Lampung. Semantic is branch core linguistic besides syntax, phonology, and morphology; as, it is stated by Kreidler (3:1989). The term semantic can refer to kinds of particular course in the university especially in the field of any linguistic, language educational study and literature. In STKIP Muhammadiyah Kotabumi, Lampung, this term was adopted as one of the course under department of English Education. It is one of the courses that is set for introducing students to some of the main concern in study of meaning. In the course, students learn about the main features, which underlined process of construction meaning such as the nature of language, semantic roles, reference and referring expression. The students mainly discuss about the definition of theory within the subject matters. After that, the students present the material according their understanding.

On the other side, lesson study for learning community is one of the program 
initiated by The Ministry of Higher Education by meant to encourage a simultaneous cooperation among stakeholder of education. By using this program, the process of teaching and learning activity in the classroom will be drag into a cooperative process among lecturer and stakeholder. The program itself is divided into 3 steps which are planning, doing and reflection (read: plan, do, see). In the planning phase, lecturer was demanded to present a systematic process of teaching in the lesson design. The lessson design will be discussed among the observer that were come from collegues or another stakeholder. The observer can suggest some opinion for the improvement of the lesson design. After having the planning step, the lecturer was doing the "do" activity where lecturer was implementing teaching learning process based on the lesson design. After finishing the "do", lecturer was conducting the last activity that was the "see" where the lecturer was reflecting the teaching learning process that he conducted and ask the suggestion from the observer.

\subsection{Teaching semantic by using jigsaw model}

Basically, during teaching learning activity, lecturer used many strategies to support the teaching and learning activity. Almost all of the courses were supported by main reference and supplement for reading material, including for "Semantic" course. The lecturer will ask the students to prepare the material by reading the reference book that lecturer suggested in the first meeting of the semester. Before the meeting was conducted, students had plenty of time to ask for explanation regard to the material that they did not understand.

Teaching semanctic considered as difficult because of the abundant material that lecturer need to deliver while the time is limited to cover all. Therefore, the lecturer faced a dilemma, moreover the complexity of the material was also another challenging issue. Considering all the problem, lecturer tried to use Jigsaw model. Jigsaw model consider as a cooperative approach which encourage all the students to engage into the learning process. According to Weidman and Bishop (2009) in Garcia (2017), the jigsaw method typically follows a specific sequence of events. The first step occurs when the instructor has decided upon a topic to be researched or presented, then afterwards students are then divided into small cooperative groups. Moreover, by using this kind of learning model, lecturer can encompass a wide material with limited time. The process of teaching using jigsaw method was a simple process consists of main activity which is divided students into two kind of group: jigsaw group and expert group. The jigsaw model is organizing classroom activity that makes 
students dependent on each other to succeed. It breaks classes into groups and breaks assignments into pieces that the group assembles to complete the (jigsaw) puzzle. The model splits classes into mixed groups to work on small problems that the group collates into a final outcome. For example, an in-class assignment is divided into topics. Students are then split into groups with one member assigned to each topic. Working individually, each student learns about his or her topic and presents it to their group. Next, students gather into groups divided by topic. Each member presents again to the topic group. In same-topic groups, students reconcile points of view and synthesize information. They create a final report. Finally, the original groups reconvene and listen to presentations from each member. The final presentations provide all group members with an understanding of their own material, as well as the findings that have emerged from topic-specific group discussion.

\subsection{Objective of the Study}

Regard to the importance of this course for enhancing students' competence and performance and due to the lack of investigation on this field of interest, researcher tends to explore teaching "Semantic" by using jigsaw model within the LSLC implementation. According to Saito (2015), LSLC is about learning communities at so many levelsteacher communities, student communities, parent communities and the interfaces between and among them. And the heart of these communities is dialogue and of developing a listening relationship within and among these commnities. Moreover, fewer are no research has investigated such perceptions or beneficial effect for Indonesia candidate of EFL lecturer. So, the present study addresses itself to this nearly neglected area and deals with only about analyzing of teaching "Semantic" by using jigsaw model within the LSLC implementation to students of English lecturer training and pedagogy in STKIP Muhammadiyah Kotabumi, Lampung.

\subsection{Research Question}

Due to the nature of this study, it responded the following research question: how was teaching "Semantic" by using jigsaw model within the LSLC implementation to students of English lecturer training and pedagogy in STKIP Muhammadiyah Kotabumi, Lampung.

\section{METHODOLOGY}

\subsection{Research Design}

In this research, researcher applied narrative research designs. As it is stated by Connelly \& Clandinin (1990) in Creswell 
(2012), that in narrative research designs, researchers describe the lives of individuals, collect and tell stories about people's lives and write narratives of individual experiences. Researcher used it by intention to analyze teaching "Semantic" by using jigsaw model within the LSLC implementation to students of English lecturer training and pedagogy in STKIP Muhammadiyah Kotabumi, Lampung. Based on Suparno (2008), classroom (PTK) is the research actions taken by the teacher with the aim to improve the quality of learning in the class implementation.

\subsection{Participant}

Participants of the research were the students from the seventh semester of English department STKIP Muhammadiyah Kotabumi, Lampung. There were several reasons why researcher chose the participants. The first reason was because this research was on going process of LSLC implementation which was conducted in STKIP campus. The second reason was because the participants were accessible by researchers. Third was because participants have been teaching "Semantic" in STKIP Muhammadiyah Kotabumi, Lampung.

\subsection{Research Instrument}

In conducting the research, the researcher will use observation sheet as the research instrument. The observation sheets are adopted from LSLC observer sheet that was used during observation process. By using the questionnaire, the researcher knew classroom condition, teaching learning process and observer point of view toward teaching semantic by using jigsaw model when LSLC program was being implemented.

\section{FINDINGS AND DISCUSSION}

1. Initial Condition of Student Learning Results

Prior to the implementation of research jigsaw method, based in the classroom observation sheet, it is stated that teaching learning process considered good even though the researcher still found several weeknesses regard to time and classroom management. In the time management, it was found that a limitation of the time during teaching learning process was quite an issue. It happened due to a wide range material that need to be understood by students meanwhile the time was not sufficient. In the part of classroom management, lecturer need to divide students into several group which made the class quite crowded.

Based on the observation, it was necessary for the lecturer to create and improve the conducive classroom situation, the students are actively involved in learning, the occurrence of two-way communication, and the students increase their motivation to learn. 
Teaching and learning by using jigsaw model in semantic course when impementing LSLC program can be done in three cycles.

\section{A. Cycle I}

1. Planning

1) The lecturer made a lesson design and prepares the material to be taught.

2) The lecturer presented the lesson design in front of observer.

3) The lecturer assigns the students to bring the reference book.

4) The lecturer prepares worksheets for students.

5) The lecturer divides the students into groups of 5 children.

\section{Doing}

1) Before starting the lesson, lecturer does the ice breaking activity, to foster interest in learning.

2) Each of the students grouped into expert group which discuss the same material within each of the expert group.

3) Lecturer assigned student some task to trigger student curiosity.

4) Students returned to jigsaw group or source group.

5) Each of the students shared the material that they already knew from the expert group.
6) Once again teacher gave a guide question to trigger students curiosity toward the material.

7) Students wrote essay about the material that they aready learned based on their understanding.

\section{Reflection}

Based on the results of the observation, it is showed an increase in student learning outcomes even though there are fewer students in cooperation in the group. Some students are still busy playing themselves and time allocation for learning that was very limited.

\section{B. Cycle II}

\section{Planning}

1) The lecturer made a lesson design and prepares the material to be taught.

2) The lecturer presented the lesson design in front of observer.

3) The lecturer assigns the students to bring the reference book.

4) The lecturer prepares worksheets for students.

5) The lecturer divides the students into groups of 5 children. 


\section{Implementation}

1) Before starting the lesson, lecturer does the ice breaking activity, to foster interest in learning.

2) Each of the students grouped into expert group which discuss the same material within each of the expert group.

3) Lecturer asigned student some task to trigger student curiosity.

4) Students returned to jigsaw group or source group.

5) Each of the students shared the material that they already knew from the expert group.

6) Once again lecturer gave a guide question to trigger students curiosity toward the material.

7) Students wrote essay about the material that they aready learned based on their understanding.

\section{Reflection}

Observations made in cycle II of student participation to the group showed that the participation of students in the group was good, although there is still one less student in group participation.

\section{Cycle III}

1. Planning

1) The lecturer made a lesson design and prepares the material to be taught.
2) The lecturer presented the lesson design in front of observer.

3) The lecturer assigns the students to bring the reference book.

4) The lecturer prepares worksheets for students.

5) The lecturer divides the students into groups of 5 children.

\section{Implementation}

1) Before starting the lesson, lecturer does the ice breaking activity, to foster interest in learning.

2) Each of the students grouped into expert group which discuss the same material within each of the expert group.

3) Lecturer asigned student some task to trigger student curiosity.

4) Students returned to jigsaw group or source group.

5) Each of the students shared the material that they already knew from the expert group.

6) Once again lecturer gave a guide question to trigger students curiosity toward the material.

7) Students wrote essay about the material that they aready learned based on their understanding. 


\section{Reflection}

The impact of treatment on cycle III begins with the moment of reflection cycle II effect on student learning outcomes. Reflection of the learning process in cycle I, cycle II is very influential on the third cycle in increasing student value. In addition, the introduction of learning model jigsaw in teaching is also fostering student motivation in following the lessons. It is shown from the high concentration of students in following the lesson where there are no students who speak for themselves or play alone and whole material can be covered with enough amount of time.

The results of the study have revealed that teaching by using jigsaw model can influence teaching learning activity althought it was not a sudden process. It can be seen in the first and second cycle where it is still can be found a flawless within the process of teaching but it can be fixed over the time. As it can be seen in the result of the reflection in third cycle, the result was students tended to be more concentrated to the lesson as it was explained in reflection of the cycle III.

Not only students can feel beneficial influence of the using of jigsaw model in teaching semantic, but also lecturer too. Lecturer felt the beneficial of teaching using jigsaw model considering it can make time allocation for a wide varities of material was not an issue anymore. The lecturer can cover a wide material with enough amount of time while each of the students involved into the lesson and worked during the learning process.

On the other side, the implementation of LSLC in the teaching learning activity also brought a beneficial effect. The beneficial effect can be directly felt by the leacturer who became the model lecturer. The lecturer was helped by the existence of lesson design. The lesson design is so simple and applicable for teaching learning. Morever the 3 activities (plan, do, see) in the implementation of LSLC can make the teaching and learning process organized sytematically and made the lecturer knew their weeknesess and overcame it.

\section{CONCLUSION}

The findings showed that there are some benefits of teaching "Semantic" using jigsaw model when the LSLC program was being implemented. The benefit can be seen from 2 sides. The first benefit is because of jigsaw model itself. The second is because of LSLC implementation. Due to the use of jigsaw, model lecturer can make student enggage within the teaching learning activity while lecturer can cover wide material that need to be taught to the students. Meanwhile, because of the LSLS implementation, teaching learning activity tended to be more organized and some 
flawlesses of teaching can be seen and solve due to the involvement of observer. Moreover, the cooperative teaching among lecturer within the university can be achieved.

\section{REFERENCES}

Cresswell John W. 2012. Educational Research: Planning, Conducting and Evaluating Quanitative and Qulitative Research. Boston: Pearson Education.

Garcia, Alejandro, et.al. 2017. Using the Jigsaw Method for Meaningful
Learning to Enhance Learning and Rentention in an Educational Leadership Graduate School Course. Global Journal of HUMANSOCIAL SCIENCE: G Linguistics \& Education Vol 17 Issue 5.

Kreidler, Charles W. 1989. Introducing English Semantics. New York: Routledge.

Saito, Eisuke, et.al. 2015. Lesson Study for Learning Community: Aguide to sustainable school reform. New York: Routledge.

Suparno, Paul. 2008. Riset Tindakan untuk Pendidikan. Jakarta: PT Gramedia Widia Sarana Indonesia. 